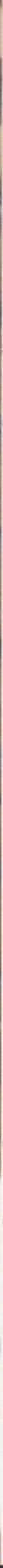




\section{MODERN KAKIEMON WARES - THE DIGNITY OF YOHAKU (BLANK SPACE)}

The Kakiemon exhibition currently being held at the Princessehof Museum in Leeuwarden is of great interest. This exhibition showcases important collections of Kakiemon wares from across the Netherlands. Kakiemon wares - Japanese polychrome porcelain of the highest quality produced in Arita, Kyushu - were first exported to Europe during the late $17^{\text {th }}$ century. These wares achieved great popularity among the European aristocracy, especially among the princesses of the House of Orange, and have been employed in grand decorative elements in noble palaces ever since. Visitors will be impressed by the exquisite enamelled porcelain on display in the Princessehof museum. However, the most unique and fascinating part of this exhibition is the introduction of modern Kakiemon wares produced by $12^{\text {th }}-, 13^{\text {th }}-$, and $14^{\text {th }}$. generation creators of Sakaida Kakiemon. There have been many exhibitions and studies of Kakiemon all over the world, but modern Kakiemon wares have until now not been fully recognised worldwide. In this article, I would like to provide an introduction to the history and beauty of Kakiemon wares of the modern period.

\section{The Kakiemon kiln and the Kakiemon style}

The Kakiemon kiln is one of the most celebrated Japanese porcelain kilns and has been maintained in Arita since the $17^{\text {th }}$ century. The Sakaida family possesses an ancient document stating that Kakiemon I succeeded in producing overglaze enamelled porcelain for the very first time in Japan during the 1640s. The kiln has produced porcelain ever since, and the name Kakiemon has been inherited by successive heads of the Sakaida family. The present head of the kiln is Sakaida Kakiemon XIV (b.1934). The Kakiemon style refers to the style of overglaze enamelled porcelain believed to have been perfected at the Kakiemon kiln during the 1670 s. The main characteristic of this style is the composition of design, in which stylised motifs are painted asymmetrically, intentionally leaving ample blank space to emphasise the whiteness of the porcelain. The motifs are decorated in overglaze enamels, the colours of which are limited to red, yellow, turquoise, blue, purple, and gold, according to a secret document Akaenogu oboe ("Memorandum on a recipe of enamel pigments'), preserved in the Sakaida family and dated 1690. Red is the most important and characteristic colour of the Kakiemon style, not only because it is the brightest and most beautiful in the palette but also because it enables the expression of subtle nuance. Other porcelain kilns in Arita soon started to produce wares in this style, when the style's enormous popularity in Europe became evident. Queen Mary II is well known to have been a passionate collector of Kakiemon. In Hampton Court Palace in England, Kakiemon wares considered to be from her collection are still to be seen. 
In about the 1690s, the Kakiemon kiln and other Arita kilns began to produce Kinrande-style wares: porcelain with busy, flamboyant decoration in underglaze blue and red, green, yellow, purple, and gold enamels, which also achieved great popularity in Europe. ${ }^{1}$

The demand for Japanese porcelain, however, fell markedly by the middle of the $18^{\text {th }}$ century, and the Dutch East India Company (VOC) stopped importation in 1757. Consequently, the Kakiemon kiln discontinued the production of export porcelain, and this was one of the factors that seriously affected the business financially. The kiln struggled to preserve the quality and techniques of Kakiemon wares, although it did manage to maintain production by directing attention towards the domestic market. Nevertheless, the production of nigoshide, the extremely refined milk-white body, which is an important criterion for the typical Kakiemon style, ceased for more than 250 years, until Kakiemon XII and XIII recreated it in $1953 .{ }^{2}$

\section{Kakiemon wares in the late Edo to Meiji period}

During the late Edo period, the Kakiemon kiln produced mostly blue-andwhite wares and polychrome wares with underglaze blue. These wares were clearly different in style and quality from those of the late $17^{\text {th }}$ century. Japan was in political turmoil from the late Edo period to the middle of the Meiji period. The Arita porcelain industry lost the patronage of the Nabeshima clan, ${ }^{3}$ following the collapse of the samurai class, and had to survive alone in the domestic market. ${ }^{4}$ It is not hard to imagine that it would have been difficult for the Kakiemon kiln in such a situation to maintain the quality and techniques of Kakiemon wares, let alone try to restore its reputation.

It was in the time of Kakiemon XI (1845-1917) that the Kakiemon kiln started to gain a foothold in this quest. Kakiemon XI devoted all his energy to restoring the reputation of the kiln and regaining the quality of Kakiemon at its peak. According to Kakiemon XIII, in his memoir Akae ujyo, Kakiemon XI was a capable businessperson who hired a number of artisans and promoted sales of Kakiemon wares all over Japan, as well as being a talented potter who won prizes at the Columbus World Exposition in 1893 and the San Francisco World Exposition in 1894. ${ }^{5}$ Fig. 2 shows a vase produced by Kakiemon XI in about 1915. It is decorated with the motifs of dragon, hoo (mythical bird), and karakusa scrolls in underglaze blue and red, green, yellow, purple, and gold enamels. It has the cursively written fuku mark (uzufuku) on the reverse. With fine cobalt blue and skilful painting, the decoration of the vase is distinguished, and demonstrates Kakiemon XI's efforts to restore the quality and style of Kakiemon wares.

Kakiemon XI, however, did not leave much money when he died in $1917 .^{\circ}$ His son Kakiemon XII succeeded to the Kakiemon kiln, but the business soon fell into financial problems. In 1919, a businessman named Obata Hideyoshi offered to invest in the Kakiemon kiln, and together they founded Kakiemon Co. Ltd., on the condition that the kiln allowed the use of the fuku mark within a square ( $k a k u f u k u$ ) and a technical tie-up with the company for 50 years. However, Kakiemon XII was offended by Obata's policy of massproducing low-quality Kakiemon wares, and left the company in 1928.

Fig. 3 is a lidded octagonal bowl produced by Kakiemon XII after 1928. It is very difficult to make a lid that fits a main body, since porcelain clay shrinks 

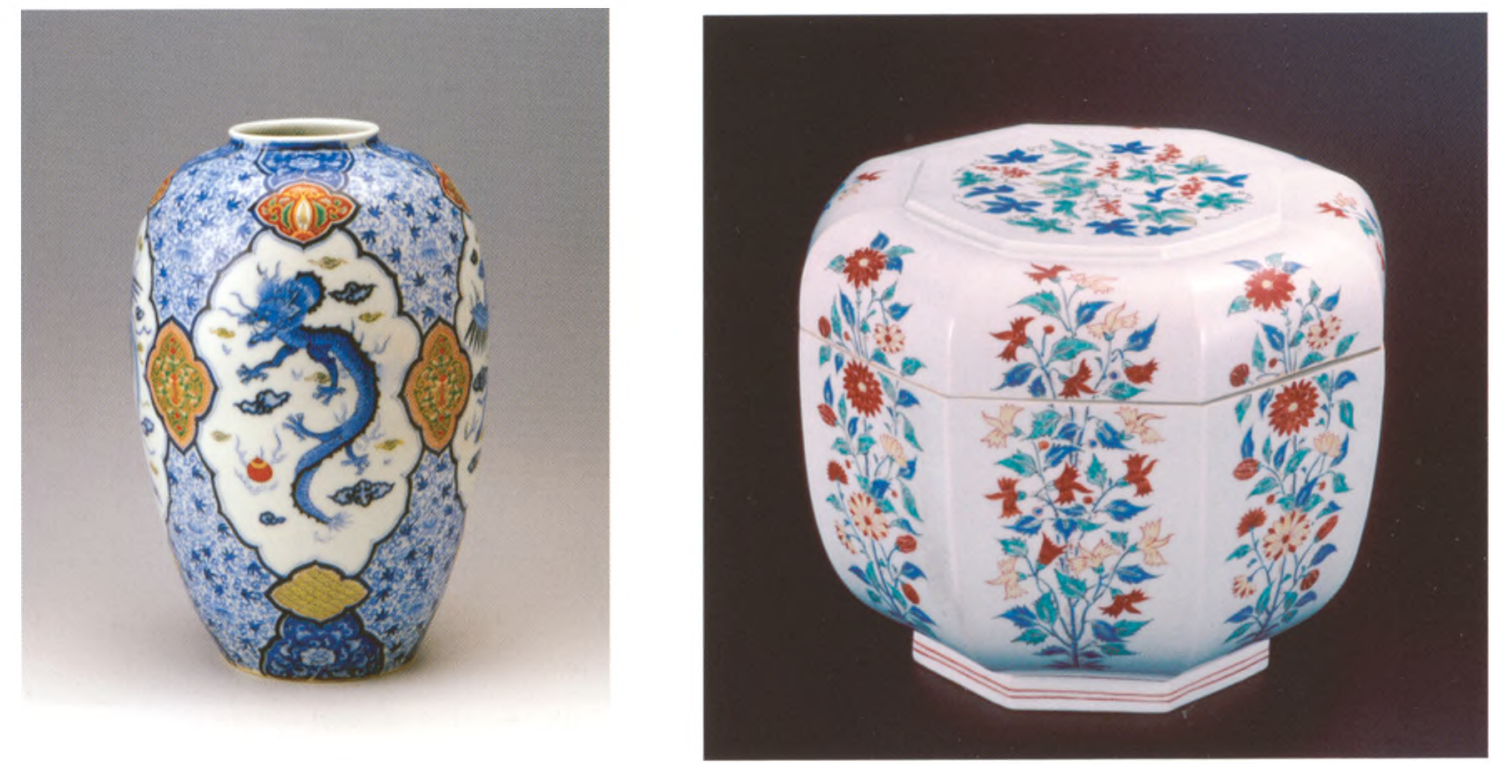

Figure $2>$

Vase, Kakiemon XI, about 1915.

Credit: the Kyushu

Ceramic Museum, Arita

Figure 3 > Lidded octagonal bowl, Kakiemon XII, after 1928.

Credit: Kakiemon kiln during firing. The highly developed skill in producing a perfect form and the beautiful decoration of this object suggest Kakiemon XII's determination to produce only high-quality Kakiemon wares and to maintain the traditional techniques by himself. From that time, he started to use the signature Kakiemon saku ('made by Kakiemon') instead of the kakufuku mark. Subsequently, until the end of the 50-year contract in 1969, two types of Kakiemon were produced: those produced at the Kakiemon kiln, and those made by Kakiemon Co. Ltd., which was owned by the Obata family. Kakiemon wares by the Obatas bear the kakufuku mark with a signature of the company, and are generally called 'Obata Kakiemon', to be distinguished from Kakiemon wares made by the Kakiemon kiln. ${ }^{7}$

Japan also suffered financial difficulties and a lack of resources during the Depression (the 1930s) and World War II (1939-45.) Consequently, the production of porcelain was restricted by the government. ${ }^{8}$ Under such conditions, the Kakiemon kiln was in a critical condition. Kakiemon XII was a highly skilled artisan who mastered Kakiemon painting style, but knew little about business. Returning from military service in 1939, Kakiemon XIII began to take over the management of the kiln. ${ }^{9}$ The tasks given to Kakiemon XIII were to restore the kiln and to stabilize its business. His wish to improve Kakiemon wares in order to recover the kiln's business seems to have later changed into an ambition to create innovative and modern Kakiemon wares.

\section{The restoration of 'nigoshide' by Sakaida Kakiemon XII and XIII}

It is no exaggeration to say that the history of modern Kakiemon wares began with the re-creation of nigoshide by Sakaida Kakiemon XII and XILI $\mathrm{L}_{20} \mathrm{a}_{3}$ quest which started in about 1949. As mentioned earlier, the Kakiemon kilin dide access 

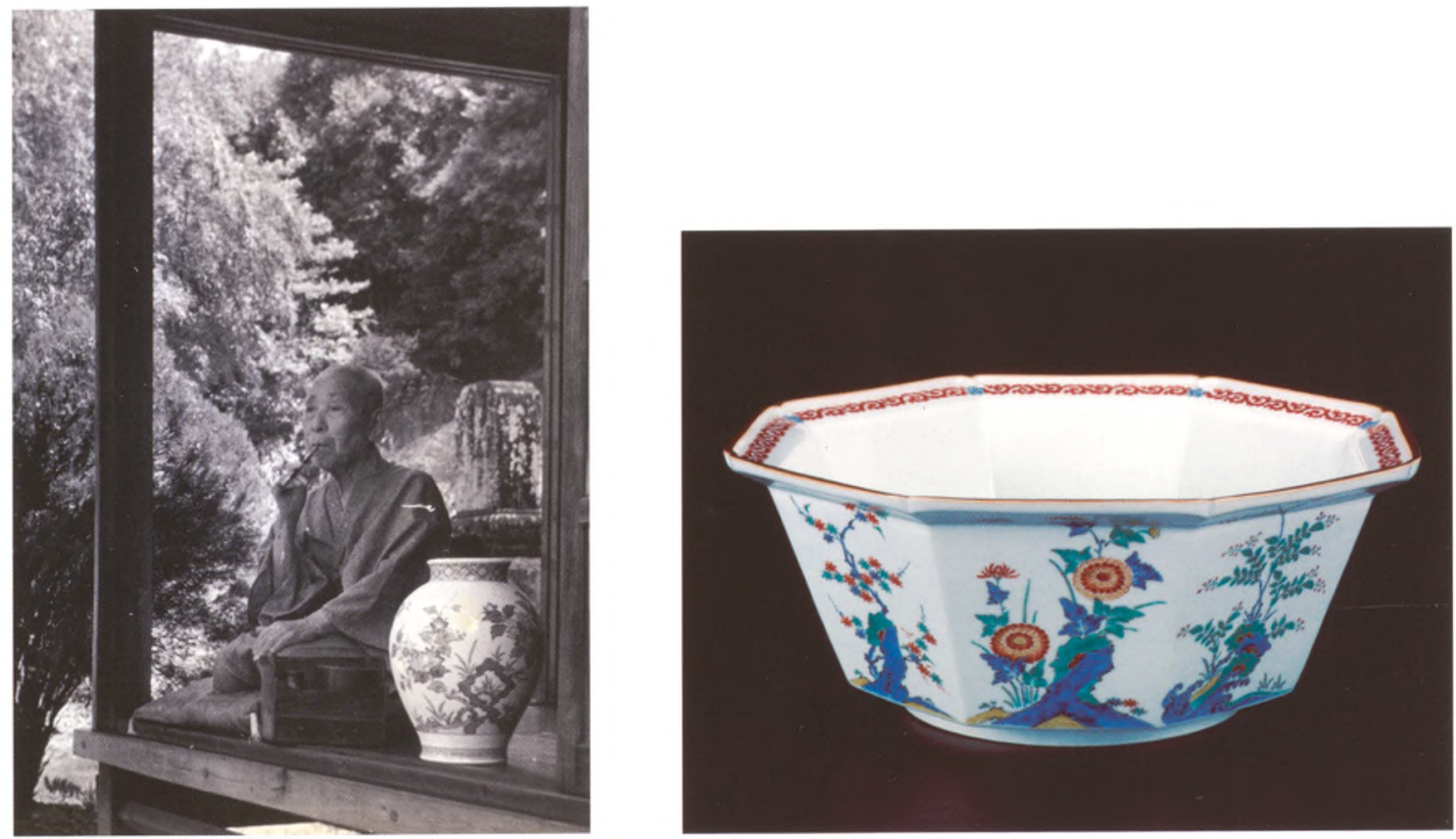

Figure $4>$ Kakiemon XII. Credit: Kakiemon kiln

Figure 5 > Nigoshide octagonal bowl, Kakiemon XII and XIII, 1955. Credit:

Kakiemon kiln produce Kakiemon wares with other types of body. However, nigoshide had remained symbolic of the Kakiemon style and the kiln, and indicative of whether the kiln was maintaining highly developed techniques. The restoration of nigoshide meant the re-creation of Kakiemon style of the best period. Following the guidance of the ancient document Tsuchi awase cho ('Notebook on Preparation of Clay Bodies'), Kakiemon XII and XIII tested the composition of clay repeatedly. However, the materials are not homogeneous in quality, and differed from those of the Edo period. Nigoshide is a compound of three types of clay from the quarries at Izumiyama, Shirakawadani, and Iwayagawachi, and mixing the clay is very complicated. ${ }^{10}$ If too much Shirakawadani clay is added, the biscuit body cannot withstand high temperatures and tends to lose its shape, while an excess of Iwayagawachi clay tends to induce poor firing. ${ }^{11}$ In addition, the compounded clay tends to be so delicate that it breaks easily during firing. In 1953, after years of effort, Kakiemon XII and XIII finally succeeded in re-creating nigoshide.

In 1953, the nigoshide works were exhibited at a commemorative exhibition of the revival of nigoshide, which was held simultaneously with Shodai Kakiemon 300nen Kinensai (The 300th anniversary of Kakiemon I). Furthermore, a work by Kakiemon XII, a nigoshide octagonal bowl with a flower and grass design, won the President Prize at the $2^{\text {nd }}$ Japan Traditional Crafts Exhibition in 1956, and passed into the hands of the President of India at that time. It was at this moment, after more than two and a half centuries, that the restoration of the authentic Kakiemon style was finally achieved. Since then, the reputation of the Kakiemon kiln has risen steadily and its business has become stable. Fig. 5 is an early reproduction of the classic nigoshide octagonal-shaped bowl created by Kakiemon XII with XIII's assistance in 1955. It is decorated in the typical Kakiemon style with chrysanthemum and flowering plant motifs, in red, yellow, blue, turquoise, $06: 32 \mathrm{Am}$ and light brown, outlined in black. The border is embellished with a karakusacess 
pattern in red, which is tightened with an iron-oxidised rim. On the back is the signature of Kakiemon XII painted in overglaze blue. The body appears extremely refined with a thin glaze. The quality of enamel is much improved in transparency and brightness compared to that of the Meiji period and turquoise has been added once again. We are able to say that Kakiemon XII and XIII succeeded in restoring all aspects of the style typical of Kakiemon at its peak.

\section{The emergence of modern Kakiemon wares - the style of Kakiemon XIII}

Sakaida Kakiemon XIII was born in 1906 as the first son of Kakiemon XII. He joined the Kakiemon kiln in 1924, after studying ceramics at Arita Technical High School for three years. Following the death of Kakiemon XII in 1963, XIII succeeded to the kiln and officially changed his name from Shibuo to Kakiemon XIII, at the age of 57. This was a time when the Japanese economy was in a high-growth period, and this also affected the Arita porcelain industry. Petroleum kilns replaced coal-fired kilns, and the porcelain production process was industrialised, neglecting traditional techniques. Faced with such a situation, the Kakiemon kiln was determined to preserve traditional techniques. Attitudes were also changing. From the middle of the Taisho period (1912-26), there had been a public tendency to differentiate 'ceramic artists' from potters (or artisans): the former being generally those who hereditarily succeeded to the family's profession.

However, in the modern period, with the emergence of ceramic artists such as Kenkichi Tomimoto (1886-1963) and Shoji Hamada (1894-1978) who won reputations worldwide, being a potter became a popular occupation. These 'artist potters' blurred the boundaries by choosing to become independent potters, creating ceramics in their own original style, unrestricted by tradition. Their concept was new and innovative, and we can imagine that it had a great influence on the thoughts of potters who were bound by tradition. Since then, traditional potters have been caught in a dilemma between creating modernity and following tradition. This illustrates the way in which the circumstances surrounding Kakiemon have changed from those of previous generations.

Kakiemon XIII always argued that he must bring a sense of modernity and originality into the Kakiemon style, and was often opposed to the style of Kakiemon XII, who faithfully followed tradition. ${ }^{12}$ However, Kakiemon XIII had no intention of losing the tradition. Indeed, he says, 'We must look at the true value and beauty of the old porcelain, in the meantime developing our individuality. ..... It's easy to say, 'Develop your individuality', but it takes 20 to 30 years to achieve it. ${ }^{13} \mathrm{He}$ believed that potters should master the old style and techniques first, and then become able to work on developing their own style. His view seemed to match the concept of the Japan Traditional Crafts Exhibition, which was established for the purpose of preserving and developing the tradition of Japanese art crafts in $1954 .{ }^{14}$ The concept of the exhibition is 'Tradition is alive; while maintaining the intrinsic qualities, it undergoes an unceasing evolution. Traditional art crafts are not mere copies of previous works made faithfully following the existing techniques. Tradition is the basis of art craft, and it is our duty to learn it well, further refine the excellent skill which has been handed down through many generations, and create new works suitable to modern living.' ${ }^{15}$ It is reasonable to say thatee access 

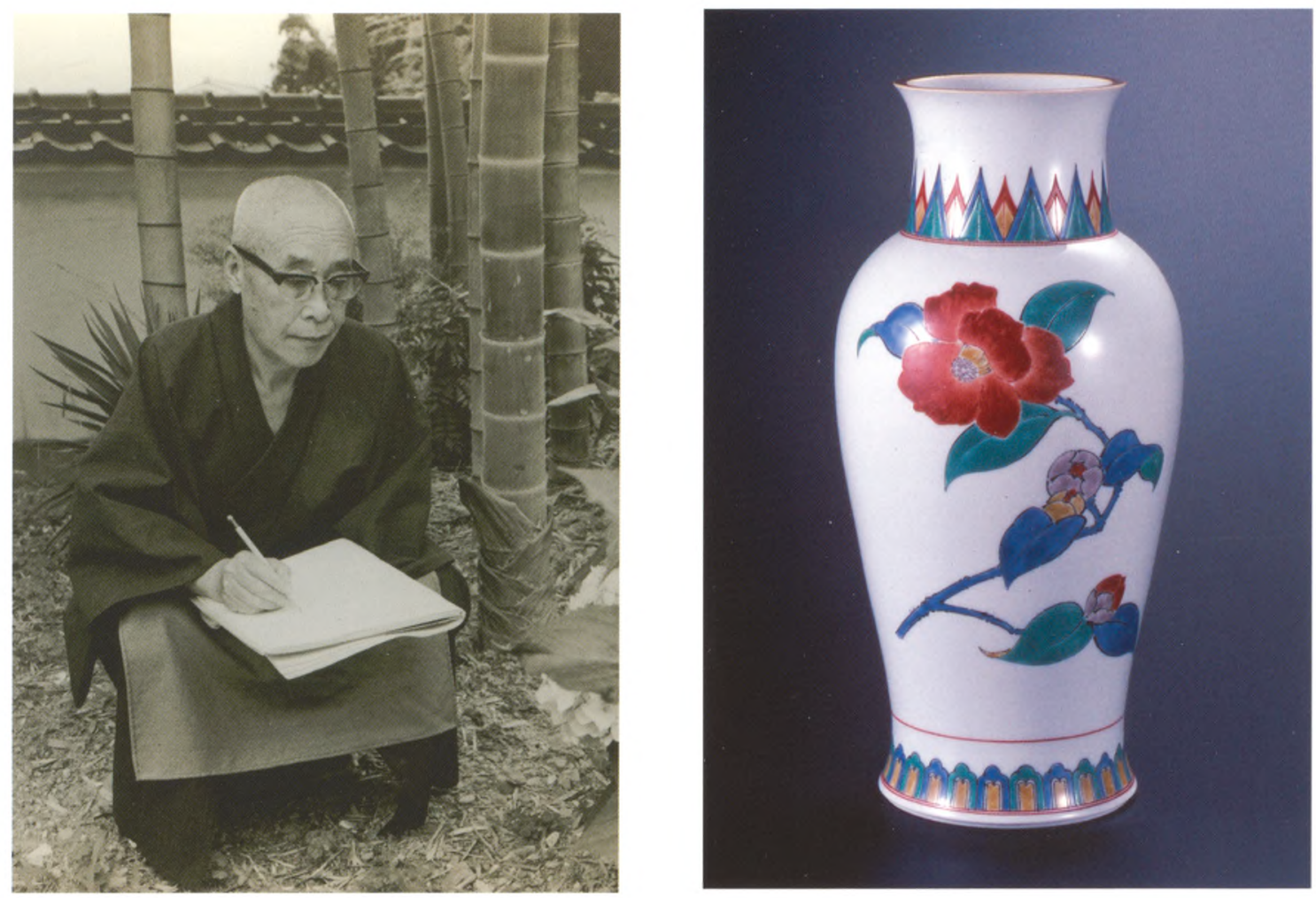

Figure $6>$

Kakiemon XIII.

Credit: Kakiemon kiln

Figure $7>$

Nigoshide vase,

Kakiemon XIII, 1980.

Credit: Kakiemon kiln when artisans create new original styles, they can be called creative artists. Creating modernity and preserving tradition became the common task given to traditional craftsmen in the modern period. Having participated in the Exhibition since its second occurrence, Kakiemon XIII aimed to create the modern Kakiemon style as an artist, while preserving the traditional style and techniques as the successor of the Kakiemon kiln.

In his early days, XIII seems to have struggled to find the best way to make good use of both tradition and innovativeness. The public conservatives have tended to criticise him for a style that went beyond the tradition of Kakiemon style. ${ }^{16}$ However, he seems to have perfected his original modern style by around 1970. ${ }^{17}$ Fig. 7 (not exhibited) is a vase decorated with a camellia motif in red, yellow, blue, and turquoise enamels, with black outlines, produced by XIII in 1979. The scale of the single camellia motif feels bold and new, but the decoration does not lose the graceful atmosphere of the traditional Kakiemon style. The works of XIII seem to have an added dimension of novelty, unlike those of Kakiemon XII, who faithfully followed the traditional style.

While Kakiemon XII was the master of porcelain painting, Kakiemon XIII was the talented thrower. XIII created a lot of unique and modern shapes. He was also innovative in the application of techniques and style. XIII transformed the classic Kakiemon style; he applied a technique in which flower motifs were painted only in gold outlines and effectively used the white background as a part of the colour of flowersadVisitors will be impressed by 6: 32AM the novel and modern style of XIII. 
Figure 8 Nigoshide lidded box, Kakiemon XIII, 1978. Credit: Kakiemon kiln
He also applied motifs of fruit and flowers based on his own original sketches. We may say that the use of sketches was revolutionary in the history of Kakiemon wares, because all the previous Kakiemons only used designs from pattern books called egashira, which were based on Japanesestyle painting, and were kept at the Kakiemon kiln. XIII made a large number of sketches, and sought new motifs for new modern Kakiemon wares. Fig. 8 shows a large lidded box decorated with celosia motifs in the Kakiemon palette. A large celosia motif painted over the lid looks fresh and novel, and this displays the uniqueness of Kakiemon XIII in choosing 'non-classic' celosia motifs for the decoration.

In 1950, the Law for the Protection of Cultural Properties was brought in, and it was amended in 1954. Under this law, the Agency for Cultural Affairs of Japan selects the most important cultural properties to be protected and designates them as important cultural heritage or important intangible cultural heritage holders, and 'imposes restrictions on such activities as alteration of their existing state, repairs, and export' while implementing measures for their conservation and utilisation. ${ }^{18}$ These cultural properties include intangible cultural assets, such as performing arts and techniques of applied arts, as the heritage of Japanese people. For the restoration of nigoshide in 1953 by Kakiemon XII and XIII, it is thought that the Agency for Cultural Affairs had some role in encouraging the kiln to restore the technique. In 1971, Kakiemon XIII organised the Kakiemon Pottery Technique Preservation Association as the body for preserving traditional techniques. In 1976, nigoshide was designated as an Important Intangible Cultural Heritage, and the Association was appointed to the technique preservation group. The designation meant that the Kakiemon kiln is tasked 
to preserve techniques and materials of nigoshide production as a national cultural asset. Thus, Kakiemon in the modern period is responsible for the preservation of the traditional techniques and materials, while at the same time introducing novelty. The influence of Kakiemon and Iro-Nabeshima, published in 1916, should not be overlooked. In this publication by the Saikokai group, Kakiemon wares, especially milk-white porcelain decorated with overglaze polychrome enamels, were highly praised, and this attitude continued. It is therefore no exaggeration to say that these factors paved the way for the Kakiemon kiln.

Porcelain production requires skilful techniques in each process and it takes a long time to master the entire process. The Kakiemon kiln has divided the process into eight stages and each process is practised by specialized artisans: (1) throwing/casting, (2) biscuit firing, (3) underglazing, (4) glazing, (5) firing, (6) cooling, (7) overglazing, and finally (8) last firing. ${ }^{19}$ Kakiemon products are therefore not necessarily produced by the hand of the present Kakiemon only, but rather are supported in their production by specialized artisans. In the art field, it is not uncommon for artists to create works using a divided production system, especially in the area of pottery, which requires completely different techniques in each process. Furthermore, 'these techniques are not changed merely by the head of the workshop's intention. And once transmission has been broken, twice the amount of time and labour is required to re-create the skills. ${ }^{20}$ Kakiemon XIV says that he trains young artisans in the expectation that they will one day support Kakiemon $\mathrm{XV}$, just as XII and XIII trained artisans for him. ${ }^{21}$ Therefore, the role of Kakiemon is both that of a skilful artist and that of a proficient manager who directs the production process. Since only Kakiemon and highly-skilled artisans are allowed to use nigoshide, all the other Kakiemon wares are made of Amakusa porcelain clay, another refined high-quality porcelain. ${ }^{22}$ The tradition is thus continuously handed down through those artisans as well, and they are also responsible for passing it to the next generation.

We may say that the style of Sakaida Kakiemon XIII is characterized by its innovativeness and boldness. Kakiemon XIII was undoubtedly a first-class artist. However, Kakiemon XIV says, 'XIII's designs and shapes (of porcelain) were free and easy, and his style was bold. However, I believe that he was basically an 'artisan', rather than a ceramics artist. ${ }^{23}$ The artistic works of Kakiemon XIII are the results of his efforts to create high-quality modern Kakiemon wares. Kakiemon XIII said, 'To succeed tradition means following two courses; one is to make good use of old spirit, and the other is to make the most of my own spirit."24 XIII well understood the importance of mastering the traditional style and techniques, but he believed that following tradition meant not just reproducing classic works, but also developing to match the ethos of an age. He did not intend to lose the tradition, but he strove to evolve it to be appreciated as the modern Kakiemon style. He therefore always preserved the essence of the traditional Kakiemon style somewhere in his works, while introducing novelty. This could not have been achieved without his creative talent and innovation. It is no exaggeration to say that the reputation of Kakiemon wares and the Kakiemon kiln became firmly established with the emergence of Sakaida Kakiemon XIII. He showed his followers how to break through the tradition without losing it ${ }_{2}$ and sublimated it into the modern Kakiemon style. 
Sakaida Kakiemon XIV (b. 1934) succeeded to the kiln and changed his name from Masashi to Kakiemon XIV in 1982, following the death of his father Sakaida Kakiemon XIII. At least three tasks fell to the share of Kakiemon XIV: firstly, preserving the traditional Kakiemon style and techniques; secondly, developing the style of Kakiemon XIII; and finally, creating an original style of his own. The succession of the traditional Kakiemon style and technique is the inevitable task for the $14^{\text {th }}$ generation of the Sakaida family. Also, since XIII laid the groundwork for the creation of the modern Kakiemon style, the development of this style naturally follows. Finally, as Kakiemon XIV says, if 'Tradition is how to use and develop what you've learned and what has been handed down. Works created through tradition, are those in which you can feel the breath of that particular age', ${ }^{25}$ it is essential for him to create the Kakiemon style of today. For him, this last task is the most important.

Sakaida Kakiemon XIV was born the only son of Kakiemon XIII in 1934. He describes his childhood as follows: 'There was hardly any special education as a successor... The workshop was my playground, so I naturally learned pottery. ${ }^{26} \mathrm{He}$ learned drawing from his high-school teacher Furukawa, who mastered Japanese-style painting. In 1953, he entered Tama Art University in Tokyo to learn Japanese-style painting following his father's advice; Kakiemon XIII seemed to expect that the knowledge of Japanese-style painting would be a great asset to XIV in the future. He learned line drawing and techniques of using brushes and pigments from artist professors at the university, such as Arai Shori and Shimada Totsurou, and established the foundations of becoming a ceramic artist. ${ }^{27}$

He joined the Kakiemon kiln three years after he graduated from the university in 1958, and learned Kakiemon pottery techniques from Kakiemon XII and XIII. Since XIII was better at throwing than painting, XIV learned the preparation of enamels and painting techniques directly from XII. Kakiemon XIV started exhibiting his work in public with the $28^{\text {th }}$ Issuikai Exhibition in 1966, and has participated in the Japan Traditional Crafts Exhibition every year since $1968 .^{28}$

The most distinctive character of the Kakiemon XIV style is the use of many different wild plant and flower designs. Following the manner of XIII, Kakiemon XIV occasionally travels to the mountains, mainly in the Kyushu area, and makes lots of sketches of wild plants and flowers. He draws designs based on those sketches on semi-transparent Japanese paper, and experiments with colours on the designs to see if they work as decoration for porcelain. If he likes them, he outlines them in Japanese ink, and traces them onto porcelain. Kakiemon XIV normally leaves out unnecessary parts of designs in order to make them fit the three-dimensional body. ${ }^{29} \mathrm{He}$ also carefully calculates the design composition and leaves ample blank space, so as to meet the requirements of the Kakiemon style. XIV says that he uses wild plants and flower motifs for his works because he believes that those motifs are alterable and easier to apply to porcelain decoration, and match the milk-white body better than 'artificial' decorative flowers His intentional : $22 \mathrm{Am}$ use of wild plants and flowers, which were never used in Kakiemonvia free access 

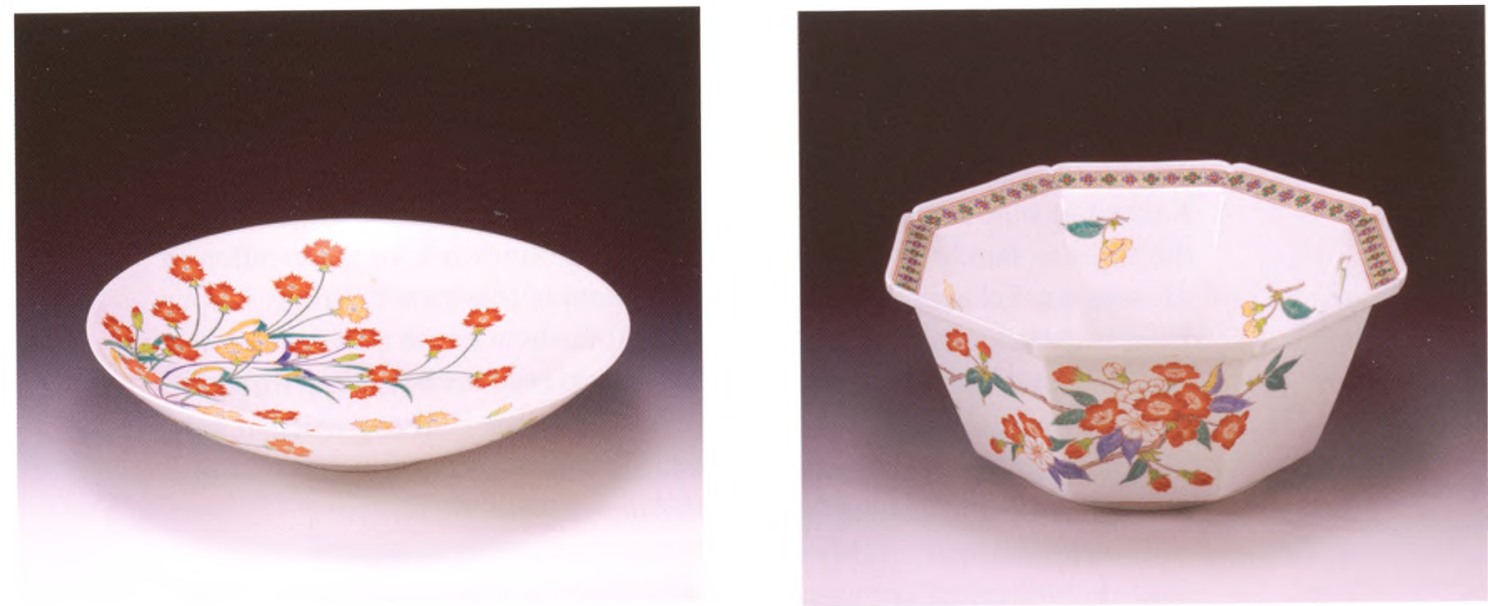

Figure 9 >

Nigoshide bowl, Kakiemon XIV, 1997. Credit: Asahi Shimbun

Figure $10>>$ Nigoshide octagonal bowI, Kakiemon XIV, 2000. Credit: Asahi Shimbun decoration in the Edo period, brings a new modern feeling to his works. ${ }^{30}$ The wild plants and flowers are painted in a gentle sophisticated manner acquired from his study of Japanese-style painting, and therefore give the impression of freshness: of having just been picked. Fig. 9 is a large nigoshide bowl decorated with wild pink designs, in the typical Kakiemon palette, outlined in black and red. The wild pinks are painted with a sense of movement, which creates an impression of freshness.

Having succeeded to the Kakiemon kiln at the age of 48 , Kakiemon XIV was given the task of preserving the traditional style and techniques as the president of the Kakiemon Pottery Technique Preservation Association. XIV was determined to emphasise the study of traditional techniques and materials and the re-creation of classic Kakiemon wares. Fig. 10 is an octagonal nigoshide bowl produced in 2000 , decorated with beautiful cherry blossom motifs in the typical Kakiemon palette. The rim is decorated with a geometric cord pattern. This octagonal form, made using a mould, was frequently used for classic Kakiemon wares of the $17^{\text {th }}$ century, but the boldly painted cherry blossom motifs are entirely new. Compared to the works of Kakiemon XIV, the painted decoration of classic Kakiemon often appears stiff and static. With development of pottery techniques and new styles from the 1980s, Kakiemon XIV has achieved expression of his originality while still retaining the traditional style.

Kakiemon XIV does not use flower motifs in combination with traditional bird or animal motifs in his original works. Ootaki states that is probably because XIV is trying to avoid giving a classic impression. ${ }^{31}$ Although this may be true, there are further reasons for XIV not using such motifs.

Kakiemon XIV himself says that he believes that these combinations do not seem to match each other very well, and furthermore that the perfection achieved in the Edo period is difficult to challenge. ${ }^{32}$ However, he is nonetheless determined to preserve such traditional motifs in the works of $06: 32 \mathrm{Am}$ the Kakiemon kiln. 
In the meantime, Kakiemon XIV has applied himself to the creation of his original works. Since XIV's succession, there has been a public expectation for him to produce works that are unique and different from the works of Kakiemon XIII. Although some artists would have created something totally unconventional to prove their difference from their predecessors, Kakiemon XIV has been working in his own way, which is maintaining a balance between the traditional Kakiemon style and modernity. XIV has followed the style of XIII, and his works may appear resemble to those of XIII. However, upon examination, there are differences in the details. XIII's paintings are bold and dynamic, showing his enthusiasm for innovation, while those of XIV have a refined elegance and a soft rhythm expressed by the brush. XIV's nigoshide appears much whiter than XIII's, which seems to be the result of his continuous efforts to improve the quality of the porcelain. It may therefore be said that Kakiemon XIV has followed the style of Kakiemon XIII and developed it into a true modern Kakiemon style.

The glaze of Kakiemon XIV's works appears glassy, which suggests that it is extremely thin. The vivid enamels, especially the red, reflect the refined whiteness of the nigoshide body. He usually uses red with green and blue to cool down the intensity of the red. This also shows XIV's dedication to the preservation of the essence of the Kakiemon style, in which the balance between colours is carefully calculated. His training in Japanese painting has given Kakiemon XIV highly developed painting skills. His style seems more pictorial and lively than that of his predecessor, but he nevertheless retains the traditional manner in form and colours. We can therefore assert that Kakiemon XIV has perfected his style and succeeded in creating harmony between tradition and modernity. In 1992, Kakiemon XIV won the Japan Traditional Crafts Association Incentive Prize, for the second time. This work was particularly highly valued by ceramic commentator Hasebe Mitsuhiko. ${ }^{33}$

\section{Untiring efforts to maintain the tradition}

Sakaida Kakiemon XIV was acknowledged as an Important Intangible Cultural Heritage Holder in 2001. This recognition is given to him personally as a ceramic artist, and is distinguished from the acknowledgement given to the Kakiemon kiln. Among thousands of potters in Japan, only nine artists and three groups are given this title. ${ }^{34}$ It is not too much to say, therefore, that Sakaida Kakiemon XIV has been recognized by the nation as one of the most prominent ceramic artists in Japan. At the same time, this confers an even greater responsibility on Kakiemon XIV to devote his life to being a great artist.

Kakiemon XIV is untiring in his efforts to preserve and also to improve traditional Kakiemon techniques. However, it is difficult to obtain pigments and glaze of the same quality as those of the Edo period. He says, 'Pigments today are chemically processed. The colour is clean and easy to manipulate, but has lost its expression, because the necessary impurities have been removed. ${ }^{35}$ The Kakiemon kiln prepares its own pigments to preserve their traditional composition. For example, rokusho (green) is made from the rust of copper plates. The kiln obtains copper plates from the roofs of old traditional Japanese houses, and soaks them in water for more than a year to desalt. Red is also made at the kiln, from bengala (ferric oxide) of $a_{3}$ high purity To produce $_{2 \mathrm{AM}}$ red, bengala is first ground in a mortar and mixed with water, and then it is leftess 


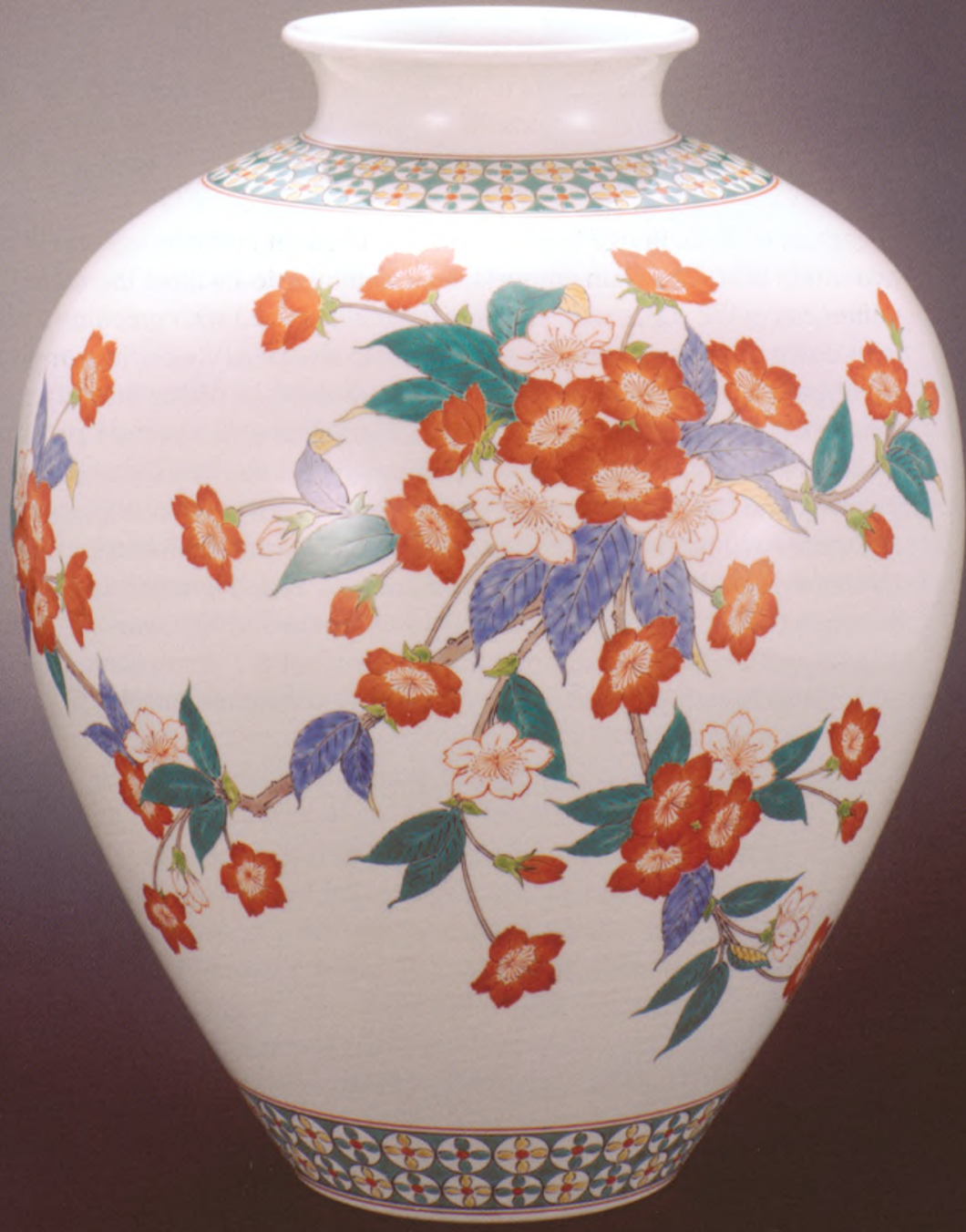




\section{< Figure 11} Nigoshide vase, Kakiemon XIV, 2003. Credit: Kakiemon kiln

\section{Figure 12} Hakogaki (sign on a wooden box) of Kakiemon XIV. Credit: Kakiemon kiln

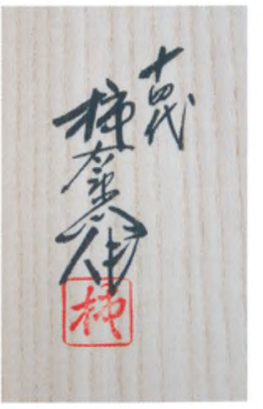

until the particles of pigment divide into three layers. The top layer produces the most vivid red, the middle one becomes a persimmon red, and the bottom layer is normally used for line drawing. Furthermore, glaze is also an important element in the creation of the ideal milk-white colour of nigoshide. The Kakiemon kiln has used a glaze made by mixing isu bark ash with porcelain clay ever since the Edo period. ${ }^{36}$ In order to obtain the ingredients for this glaze, Kakiemon XIV has planted thousands of isu on his land. It is easy to give up such a time-consuming complicated process, but Kakiemon XIV continues to make persistent and assiduous efforts to maintain the tradition.

Fig. 11 shows a large nigoshide vase decorated with cherry blossom motifs, which is the work of Kakiemon XIV after his acknowledgement as an Important Intangible Cultural Heritage Holder. The height of this vase is $46 \mathrm{~cm}$. According to the scholar Ohashi, the height of vases produced at the Kakiemon kiln in the Edo period used to be limited to about $33 \mathrm{~cm}$ (without cover) because all the products of the kiln were made by using saya ( $\mathrm{a}$ seggar), during the firing. ${ }^{37}$ Although the Kakiemon kiln continues to use saya, and to fire porcelain with firewood in a traditional kiln constructed with tonbari bricks, they are now able to produce larger pieces as pottery techniques have developed. After his succession to the kiln, Kakiemon XIV has only used the nigoshide body. Accordingly, none of his works after the succession bear his signature. Instead, the wooden boxes, which are used to protect the works, carry his signature (hakogaki) (Fig. 12)

We may say that the major defining characteristics of the Kakiemon style are refined pigments, a nigoshide body, and last but not least yohaku (blank space.) Kakiemon XIV strives for high-quality pigments and a nigoshide body because the expression of the beauty of yohaku is only possible with these materials. Kakiemon XIV says, 'I think that the whiteness of Kakiemon porcelain is created by all the artisans and workers in the Kakiemon kiln, or by each Kakiemon generation. There is always sorrow and happiness, and the whiteness of the porcelain absorbs such feelings. ... Therefore, yohaku is not just a white extra space, but the blank space into which men's hearts are put. ${ }^{38}$ Yohaku is thus more just a white space: it is possibly the most important element of the Kakiemon style, and therein resides the pride and dignity of Kakiemons and their artisans.

Kakiemon XIV is currently attempting to expand the Kakiemon palette. He is experimenting with dividing red, yellow, blue, and purple into two tones, according to the colour rules of the ancient document Akaenogu oboe. He has had several opportunities to visit the Meissen factory in Germany, and has been influenced by their use of an abundant palette. Thus, Kakiemon XIV enthusiastically continues to make an effort to develop the Kakiemon style. He says, 'Tradition is how to use and develop what you've learned and what has been handed down. Works created through tradition, are those in which you can feel the breath of tradition. ... It is important to reflect the age you are living in the work you produce... If you're not in a position where you can share joy and sorrow with others, it is impossible to make something which touches the heart of others. ${ }^{39}$

He considers that following tradition means creating novelty within ${ }_{2}$ the $e_{11: 06: 32 \mathrm{Am}}$ traditional Kakiemon style. It is very difficult to find a balance between ${ }^{\text {ree }}$ access 
innovation and retaining classic elements. However, as we have seen, the works of Kakiemon XIV show that there is always scope for a new interpretation of the Kakiemon style and the creation of innovative works within the restricted field. His works are extremely refined and modern, matching the taste of today, yet also remind us of classic Kakiemon: a testament to his enormous efforts to preserve the essence of tradition in his works. Thus we may say that Kakiemon XIV has been successful in achieving a harmony between tradition and modernity.

\section{Conclusion}

Kakiemon wares cannot be produced without the highly developed techniques and styles dating back to the $17^{\text {th }}$ century. Upon succeeding to the Kakiemon kiln, both Kakiemon XIII and XIV were required to create not just ordinary works, but Kakiemon wares for the present day. However, without a respect for tradition, their works would have lost the essential essence of Kakiemon wares. Preserving tradition means not just following the old style, but also somehow retaining elements of the classic Kakiemon style in their modern creative works. The modern Kakiemon style does not neglect tradition. It is the task of the Sakaida family and their artisans to pass it on to future generations. Kakiemon XIII showed his followers how to break through tradition without losing it, and developed it into the modern Kakiemon style. It is no exaggeration to say that Kakiemon XIII laid the groundwork for the modernisation of the Kakiemon style.

Kakiemon XIV brought his father's style forward to what may be called the modern Kakiemon wares, using his highly developed skills. The most distinctive character of Kakiemon XIV's style is the sophisticated decoration, where the porcelain appears to be used as a canvas. His training in Japanesestyle painting led to his fully developed painting technique, and elevates his painting beyond that of ordinary porcelain decoration. The flowers and plants on his works always have a particular sense of liveliness. We may say that his achievement is the result of the development of Japanese enamelled porcelain, which has survived for more than three centuries. Although the high-quality body and exquisite shapes are important characteristics of the typical Kakiemon style, the most important criterion that determines the distinguished character is overglaze enamel decoration.

When the scholar Oliver Impey asked Kakiemon XIII why he did not sign his exhibition works, he replied that 'there was no need. ${ }^{40}$ Impey thought, 'This sums it up; there is no need.' All Kakiemons create Kakiemon wares with all their heart and skill, with the ultimate goal that their works should be recognisable without necessitating a signature. Kakiemon signifies more than just one person: a collection of artisans who share the aspiration to create beautiful Kakiemon wares as part of a long and honourable history. Even without a signature, the works of Kakiemon XIII and XIV are certainly recognisable as Kakiemon wares of today. There is indeed no need. Sakaida Kakiemon XIII, XIV, and their artisans, with their highly proficient techniques and well-honed sensibility, have succeeded in achieving the harmony of tradition and modernity, and creating the innovative modern Kakiemon style. This, indeed, is the Kakiemon style of the $2 \mathrm{O}_{\text {ad }}^{\text {th }}$ and $21_{\mathrm{B}}^{\text {st }}$ centuries. 
I would like to express my deep gratitude to Menno Fitski for giving me the opportunity to participate in the modern Kakiemon section of this exhibition and to write this article, and to Mr. Kakiemon XIV Sakaida for his kind loans of all the modern Kakiemon works.

For this article, I have translated all citations from Japanese sources into English. With thanks to Harriet Impey for editing the article.

1. Although the Kakiemon kiln made a variety of products including blue-and-white, celadon, white porcelain, and figures, the enamelled wares have always been the most highly valued. The term Kakiemon wares is generally used to refer to the overglaze enamelled porcelain decorated in the Kakiemon style.

2. The production of nigoshide is thought to have ceased by the early $18^{\text {th }}$ century. See Shibata Collection (V) - Enpo-yoshiki no Seiritsu to Tenkai, exhibition catalogue The Kyushu Ceramic Museum, Arita, 1997, pp.251-252.

3. The Nabeshima clan was the feudal lord who ruled over the present Saga prefecture, including the town of Arita and part of the Nagasaki prefecture.

4. Not only the Arita porcelain industry, but all the other porcelain industries supported by feudal lords, such as Satsuma, Kutani, and Seto, also suffered in that period. See T. Kuhara, "Kaki" to "Soka-mon" to - Kindai no keifu', in: Kakiemon Imari no Seiji, Tokyo, 1983.

5. Kakiemon XI also won prizes at the $3^{\text {rd }}$ and $4^{\text {th }}$ Naikoku Kangyo Hakurankai. Kakiemon XIV Sakaida, 'Kakiemon nenpu - Sakaidake-hen', in: Kakiemon-Imari no Seiji, Tokyo, 1983, p. 61.

6. S. Kawamoto, Akae ujyo, Fukuoka, 1981, pp. 25-36. Kakiemon XI expended almost all of his time and money on those lawsuits, In 1885, Kakiemon XI had officially registered the kakufuku (uzufuku) mark as his own trademark, although it was originally from China and had been used at many potteries in Arita since the early $17^{\text {th }}$ century. He filed lawsuits against potteries that used the mark, but they did not accept that the mark belonged to the Kakiemon kiln alone, and sued and confronted him.

7. In 1951, a novelist, Hino Ashihei called Obata Kakiemon wares 'nise-Kaki' ('fake Kakiemon') in his work Sekidosai, and a lawsuit was filed against him by Obata Hideyoshi. The case aroused much controversy among the public, as to whether Obata Kakiemon wares were genuine Kakiemon wares, and it was finally reconciled in 1957. After the 50-year contract with the Kakiemon kiln ended, the Obata family started their own porcelain kiln. Ibid., p. 89.

8. Ibid., pp. 26-36.

9. Ibid., pp. 60-62.

10. Ibid., pp. 73-79.

11. Only 'Iwayagawachi' is stated as the location on the list in Tsuchi-awase-cho. Kakiemon XII and XIII had to find the location of the clay first. Ibid., pp. 73-79.

12. There seems to have been frequent gossip about quarrels between Kakiemon XII and XIII. Ibid., pp. 22-26.

13. Ibid., pp. 106-107.

14. Nihon Kogei Kai, The $51^{\text {st }}$ Exhibition of Japanese Traditional Art Crafts, Tokyo, 2004, pp. 2-3.

15. Ibid. , pp. 2-3.

16. K. Minami, Kakiemon: Nigoshide, Tokyo, 1979, pp. 34-40.

17. Ibid., p. 37. 
Fiscal 2010, VI: Preservation and Utilization Cultural Properties, http://www.bunka.go.jp/english/index.html (1 October, 2010).

19. K. Doi (ed.), Fourteenth Red., Fukuoka, 1993, pp. 36-37.

20. Ibid., p. 36.

21. Kakiemon XIV Sakaida, interview by the author, 23 July 2004.

22. Nigoshide works are generally called sakkamono, while works made of other type of body (nishikide) are called kamamono.

23. Sakaida, 23 July 2004.

24. Kawamoto, op. cit. (note 6), p. 109.

25. Doi, op. cit. (note 19), p. 54.

26. Ibid., p. 50.

27. Sakaida Kakiemon XIV, Yohaku no bi-Sakaida Kakiemon, Tokyo, 2004, p. 55.

28. Before the succession, Kakiemon XIV used his original name Masashi as his signature.

29. Sakaida, 23 July 2004.

30. Although flower motifs were frequently used on the classic Kakiemon wares, they were mostly stylized flowers such as prunus and peonies.

31. M. Ootaki, 'Sakaida Kakiemon XIV', Ningen Kokuho no waza to bi (Togei meihin shusei 3: Jiki), Tokyo, 2004, pp. 62-75.

32. Sakaida, 23 July 2004.

33. Y. Yozo, 'Sakaida Kakiemon XIV: Hito to Sakuhin', in: Ningen Kokuhou Jyu-yondai Sakaida Kakiemon Ten, Fukuoka, 2002, pp. 10-14.

34. In the ceramics department, there are currently nine artists and three groups, including Sakaida Kakiemon XIV and the Kakiemon Pottery Technique Preservation Association, designated as the most important intangible cultural heritage holders. Those holders are generally called ningen kokuho (living national treasures.) Agency for Cultural Affairs of Japan, April 2010.

35. Sakaida, 23 July 2004.

36. Isu is a type of evergreen tree that grows on mountains in a warm climate.

37. K. Ohashi, 'Hizen no iroejiki- Edozenki o chushin to shite', in: Toyo Toji 20-21, Toyo Toji Gakkai (Oriental Ceramic Society, Japan), 1993.

38. Kakiemon XIV Sakaida, Yohaku no bi, 2004, p. 161.

39. Doi, op. cit. (note 19), p. 55.

40. Doi, op. cit. (note 19), pp. 84-85. 